\title{
Comparison of secondary organic aerosol formation from toluene on initially wet and dry ammonium sulfate particles at moderate relative humidity
}

\author{
Tengyu Liu ${ }^{1}$, Dan Dan Huang ${ }^{1}$, Zijun $\mathrm{Li}^{2}$, Qianyun Liu ${ }^{3}$, ManNin Chan ${ }^{2,4}$, and Chak K. Chan ${ }^{1,5}$ \\ ${ }^{1}$ School of Energy and Environment, City University of Hong Kong, Hong Kong, China \\ ${ }^{2}$ Earth System Science Programme, The Chinese University of Hong Kong, Hong Kong, China \\ ${ }^{3}$ Division of Environment and Sustainability, Hong Kong University of Science and Technology, Hong Kong, China \\ ${ }^{4}$ The Institute of Environment, Energy and Sustainability, The Chinese University of Hong Kong, Hong Kong, China \\ ${ }^{5}$ City University of Hong Kong Shenzhen Research Institute, Shenzhen, China
}

Correspondence: Chak K. Chan (chak.k.chan@cityu.edu.hk)

Received: 28 October 2017 - Discussion started: 8 November 2017

Revised: 2 March 2018 - Accepted: 10 April 2018 - Published: 24 April 2018

\begin{abstract}
The formation of secondary organic aerosol (SOA) has been widely studied in the presence of dry seed particles at low relative humidity (RH). At higher RH, initially dry seed particles can exist as wet particles due to water uptake by the seeds as well as the SOA. Here, we investigated the formation of SOA from the photooxidation of toluene using an oxidation flow reactor in the absence of $\mathrm{NO}_{x}$ under a range of $\mathrm{OH}$ exposures on initially wet or dry ammonium sulfate (AS) seed particles at an RH of $68 \%$. The ratio of the SOA yield on wet AS seeds to that on dry AS seeds, the relative SOA yield, decreased from $1.31 \pm 0.02$ at an $\mathrm{OH}$ exposure of $4.66 \times 10^{10}$ molecules $\mathrm{cm}^{-3} \mathrm{~s}$ to $1.01 \pm 0.01$ at an $\mathrm{OH}$ exposure of $5.28 \times 10^{11}$ molecules $\mathrm{cm}^{-3} \mathrm{~s}$. This decrease may be due to the early deliquescence of initially dry AS seeds after being coated by highly oxidized toluene-derived SOA. SOA formation lowered the deliquescence RH of AS and resulted in the uptake of water by both AS and SOA. Hence the initially dry AS seeds contained aerosol liquid water (ALW) soon after SOA formed, and the SOA yield and ALW approached those of the initially wet AS seeds as $\mathrm{OH}$ exposure and ALW increased, especially at high OH exposure. However, a higher oxidation state of the SOA on initially wet AS seeds than that on dry AS seeds was observed at all levels of $\mathrm{OH}$ exposure. The difference in mass fractions of $m / z 29,43$ and 44 of SOA mass spectra, obtained using an aerosol mass spectrometer (AMS), indicated that SOA formed on initially wet seeds may be enriched in earliergeneration products containing carbonyl functional groups at
\end{abstract}

low $\mathrm{OH}$ exposures and later-generation products containing acidic functional groups at high exposures. Our results suggest that inorganic dry seeds become at least partially deliquesced particles during SOA formation and hence that ALW is inevitably involved in the SOA formation at moderate RH. More laboratory experiments conducted with a wide variety of SOA precursors and inorganic seeds under different $\mathrm{NO}_{x}$ and $\mathrm{RH}$ conditions are warranted.

\section{Introduction}

Secondary organic aerosol (SOA) is an important component of atmospheric particulate matter, which influences air quality, climate and human health (Hallquist et al., 2009). SOA is mainly formed via the oxidation of volatile organic compounds (VOCs), followed by partitioning to the condensed phase. Traditional atmospheric chemical transport models largely underestimate the levels of SOA (de Gouw et al., 2005; Volkamer et al., 2006; Hodzic et al., 2010) and the degree of oxidation (Rudich et al., 2007; Ng et al., 2010). The updated models incorporating the volatility basis set (VBS) formalism (Donahue et al., 2006) can better predict the observed SOA, but SOA formation still remains underconstrained (Shrivastava et al., 2011; Tsigaridis et al., 2014; Hayes et al., 2015; Ma et al., 2017). SOA yields in atmospheric chemical transport models are obtained from smog chamber experiments using dry seed particles (Barsanti et 
al., 2013; Mahmud and Barsanti, 2013) under dry conditions. Yet atmospheric relative humidity (RH) is often sufficiently high that aerosols often contain aerosol liquid water (ALW) due to their hygroscopic properties (Liao and Seinfeld, 2005; Lee and Adams, 2010; Guo et al., 2015; Nguyen et al., 2016). The presence of ALW in aerosols may enhance SOA formation by facilitating the partitioning of semivolatile organic compounds (SVOCs) and the uptake of water-soluble gases through aqueous-phase reactions (Hennigan et al., 2008; Lim et al., 2010; Ervens et al., 2011; Lee et al., 2011; Sareen et al., 2017). ALW may also promote photodegradation of dissolved SOA (Romonosky et al., 2015). Therefore, SOA formation under atmospherically relevant relative humidity needs to be better constrained in atmospheric chemical transport models by incorporating ALW. In addition, understanding water uptake of SOA is important for estimating its loss by wet deposition, which is not well constrained.

Aromatic hydrocarbons constitute a large fraction of the total non-methane hydrocarbons in the urban atmosphere (Calvert et al., 2002) and account for a significant fraction of SOA in urban areas (Ding et al., 2012; Zhao et al., 2017). Toluene is the most abundant aromatic hydrocarbon (Calvert et al., 2002; Zhang et al., 2016), and SOA yields from the photooxidation of toluene on dry or wet ammonium sulfate (AS) seeds have been studied by varying the RH in smog chambers. Kamens et al. (2011) observed higher yields of SOA from toluene at higher RHs. They attributed this increase to the initially wet seed particles. On the other hand, Edney et al. (2000) reported that wet seeds had no effect on the SOA yields of toluene compared with dry seeds. In these studies, different RHs used for dry- and wet-seed experiments may influence the gas-phase chemistry and complicate the comparison of SOA formation.

SOA formation on initially dry and wet AS seeds has been compared using oxidation flow reactors at the same RHs (Wong et al., 2015; Faust et al., 2017). Faust et al. (2017) found a $19 \%$ enhancement in the SOA yield of toluene on wet AS seeds over that on dry AS seeds at $70 \%$ RH. However, at such high $\mathrm{RH}$, the initially dry and water-free AS seed particles can uptake water upon SOA formation because SOA themselves can be hygroscopic, and they can also lower the deliquescence RH of the AS seeds (Takahama et al., 2007; Smith et al., 2011, 2012, 2013). The potential influence of SOA formation on the physical state of the initially dry seeds as well as on the overall water uptake by the aged particles was not explicitly discussed. In addition, the hydroxyl radical $(\mathrm{OH})$ exposure in Faust et al. (2017) was approximately $2 \times 10^{11}$ molecules $\mathrm{cm}^{-3} \mathrm{~s}$, equivalent to about 1.5 days of oxidation in the atmosphere assuming an ambient $\mathrm{OH}$ concentration of $1.5 \times 10^{6}$ molecules $\mathrm{cm}^{-3}$ (Mao et al., 2009). Atmospheric particles can undergo oxidation for as long as 1-2 weeks (Balkanski et al., 1993).

In this study, SOA formation from the photooxidation of toluene was investigated in an oxidation flow reactor at an $\mathrm{RH}$ of $68 \%$ under a wide range of $\mathrm{OH}$ exposures using ini-

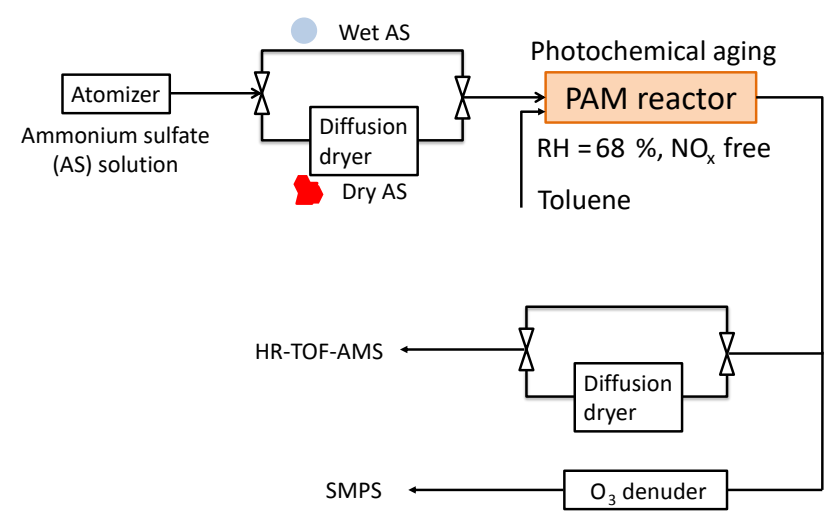

Figure 1. Schematic of the experimental setup. The aqueous ammonium sulfate (AS) seed particles either passed through a diffusion dryer so that the phase of the seed particles could be altered or bypassed the diffusion dryer. Either wet or dry AS served as seed particles for the experiments.

tially wet or dry AS seed particles. The yields and composition of SOA as well as the estimated ALW contents for the initially wet and dry seeds are compared. We found that, as $\mathrm{OH}$ exposure increased, the SOA yield and ALW of the initially dry seeds approached those of the initially wet seeds, while the wet seeds yielded SOA of a higher degree of oxidation than the dry seeds did at all exposure levels.

\section{Materials and methods}

\subsection{Generation of seed particles}

A schematic of the experimental setup, similar to that used in Wong et al. (2015) and Faust et al. (2017), is shown in Fig. 1. AS seed particles were generated from an aqueous AS solution (Sigma-Aldrich) using an atomizer (TSI 3076, TSI Inc., USA). In experiments using dry seeds, the atomized aqueous AS droplets passed through a silica gel diffusion dryer so that the RH was reduced to less than $30 \%$, at which AS effloresced, while in experiments using wet seeds they bypassed the diffusion dryer. The dry or wet seed particles then entered and mixed with a humidified $\mathrm{N}_{2}-\mathrm{O}_{2}-\mathrm{O}_{3}$ flow in an oxidation flow reactor. The RH in the flow reactor was at $68 \%$, which lies between the efflorescence and deliquescence RH of AS (Seinfeld and Pandis, 2006), so that the seed particles remained in their original phase with the wet particles containing $\sim 18.6 \mu \mathrm{g} \mathrm{m}^{-3} \mathrm{ALW}$ (see Sect. 2.4) and the dry particles anhydrous before reaction started. Hereafter, the experiments using initially wet and dry AS seed particles are simplified as wet and dry AS seeds, respectively. "Wet" and "dry" refer to the initial state of the seed particles before SOA formation. 
When atomizing a given AS solution, the diameter of wet AS droplets is much larger than that of dry AS particles due to the water uptake of AS (Chan et al., 1992), resulting in a larger surface area of seed particles. Previous studies have demonstrated that a large surface area of seed particles may increase the SOA yields by reducing the wall loss of organic vapors (Matsunaga and Ziemman, 2010; Zhang et al., 2014, 2015; Huang et al., 2016; Krechmer et al., 2016). To obtain seed particles of comparable surface areas, we atomized 0.013 and $0.015 \mathrm{mM}$ of the AS solution for wet and dry AS seeds, respectively. As shown in Fig. S1 in the Supplement, the surface area distribution of initially wet AS seeds was similar to that of initially dry AS seeds. Because of the difference in AS concentration between the stock solutions used, wet AS seeds had a mean diameter of $88 \mathrm{~nm}$ and were slightly smaller than dry AS seeds, which had a mean diameter of $102 \mathrm{~nm}$. The total surface area of wet AS seeds was $21 \%$ larger than that of dry AS seeds. The mass loading of wet and dry AS seeds was 31.0 and $24.2 \mu \mathrm{g} \mathrm{m}^{-3}$, respectively.

\subsection{Oxidation flow reactor}

SOA formation from the photooxidation of toluene in the absence of $\mathrm{NO}_{x}$ on initially dry or wet seeds was investigated in a potential aerosol mass (PAM) oxidation flow reactor, which has been described in detail elsewhere (Kang et al., 2007, 2011; Lambe et al., 2011a, 2015; Liu et al., 2017). Briefly, a PAM chamber is a continuous oxidation flow reactor using high and controlled levels of oxidants to oxidize gaseous precursors to produce SOA. The chamber used in this study had a volume of approximately 19L (length: $60 \mathrm{~cm}$; diameter: $20 \mathrm{~cm}$ ). The total flow rate in the PAM chamber was set at $3 \mathrm{~L} \mathrm{~min}^{-1}$ using mass flow controllers, resulting in a residence time of approximately $380 \mathrm{~s}$. The $\mathrm{RH}$ and temperature of the PAM outflow were measured continuously (HMP 110, Vaisala Inc, Finland) and stabilized at approximately $68 \%$ and $20^{\circ} \mathrm{C}$, respectively. High $\mathrm{OH}$ exposures were realized through the photolysis of ozone irradiated by a UV lamp $(\lambda=254 \mathrm{~nm})$ in the presence of water vapor. Ozone was produced by an ozone generator (1000BT-12, ENALY, Japan) via the irradiation of pure $\mathrm{O}_{2}$. The $\mathrm{OH}$ concentration was adjusted by varying the concentration of ozone in the PAM chamber from 0.4 to $4.3 \mathrm{ppm}$. The corresponding upper limit of $\mathrm{OH}$ exposure at these operating conditions ranged from $0.47 \times 10^{11}$ to $5.28 \times 10^{11}$ molecules $\mathrm{cm}^{-3} \mathrm{~s}$, equivalent to 0.36 to 4.08 days of atmospheric oxidation assuming an ambient $\mathrm{OH}$ concentration of $1.5 \times 10^{6}$ molecules $\mathrm{cm}^{-3}$ (Mao et al., 2009). The upper limit of $\mathrm{OH}$ exposure was determined by measuring the decay of $\mathrm{SO}_{2}$ (Model T100, TAPI Inc., USA) in the absence of toluene, following procedures described elsewhere (Kang et al., 2007; Lambe et al., 2011a). The reduction in $\mathrm{OH}$ exposure due to the addition of toluene was estimated to range from $15 \%$ at the highest $\mathrm{OH}$ exposure to $25 \%$ at the lowest $\mathrm{OH}$ exposure, using the method of Peng et al. (2016). Peng et al. (2016) found that non-OH chemistry - including photolysis at $\lambda=254 \mathrm{~nm}$ and reactions with $\mathrm{O}\left({ }^{1} \mathrm{D}\right), \mathrm{O}\left({ }^{3} \mathrm{P}\right)$ and $\mathrm{O}_{3}-$ may play an important role in oxidation flow reactors. In this study, the PAM reactor was operated at water vapor mixing ratios above $0.5 \%$ and external $\mathrm{OH}$ reactivity below $20 \mathrm{~s}^{-1}$. Non-OH chemistry is expected to play a negligible role under these conditions (Peng et al., 2016).

Before and after each experiment, the PAM reactor was cleaned under an $\mathrm{OH}$ exposure of $\sim 1 \times 10^{12}$ molecules $\mathrm{cm}^{-3} \mathrm{~s}$ until the mass concentration of background particles dropped below $3 \mu \mathrm{g} \mathrm{m}^{-3}$. After characterizing dry or wet AS seed particles for half an hour, the UV lamp was turned on to oxidize the background gases at five different $\mathrm{OH}$ levels to measure the concentrations of background organics. A toluene mixture $(29.6 \mathrm{ppm}$ in nitrogen) with a flow rate of $0.013 \mathrm{~L} \mathrm{~min}^{-1}$ was then introduced to initiate SOA formation. The initial concentration of toluene in the PAM reactor was approximately $138 \mathrm{ppb}$. The reacted and final concentrations of toluene were calculated from the $\mathrm{OH}$ exposure and the rate constant of the reaction between toluene and $\mathrm{OH}$ (Atkinson and Arey, 2003) (Table 1). The flow and light conditions were the same for initially wet and dry seeds. Therefore, the quantification of toluene would not introduce uncertainties to the relative SOA yields described in Sect. 3.1 as the initial concentrations of toluene and $\mathrm{OH}$ exposures were the same for both cases. SOA was measured for at least an hour with a stepwise increase in the five $\mathrm{OH}$ levels.

\subsection{Characterization of non-refractory components}

The AS-SOA mixed particles were characterized for the chemical composition of non-refractory components including organics, sulfate and ammonium as well as the elemental ratios of organics using a high-resolution time-of-flight aerosol mass spectrometer (hereafter AMS, Aerodyne Research Incorporated, USA) (DeCarlo et al., 2006). The instrument was operated in the high-sensitivity $\mathrm{V}$ mode and the high-resolution $\mathrm{W}$ mode, alternating every $1 \mathrm{~min}$. The toolkits Squirrel 1.57I and Pika 1.16I were used to analyze the AMS data. The molar ratios of hydrogen to carbon $(\mathrm{H}: \mathrm{C})$ and oxygen to carbon $(\mathrm{O}: \mathrm{C})$ were determined using the Aiken method (Aiken et al., 2007, 2008). The ionization efficiency of the AMS was calibrated using $300 \mathrm{~nm}$ ammonium nitrate particles. The particle-free matrix air, obtained by passing the airflow from the PAM reactor through a HEPA filter, was measured for at least $20 \mathrm{~min}$ before each experiment to determine the signals from major gases.

The collection efficiency (CE) of an AMS is dependent on the chemical composition and acidity as well as the phase state of particles (Matthew et al., 2008; Middlebrook et al., 2012). Matthew et al. (2008) found that the CE for solid particles thickly coated with liquid organics was $100 \%$. In this study, experiments were conducted at an RH of $68 \%$, exceeding the RH threshold for the semisolid-to-liquid phase 
Table 1. Summary of the results for the initially dry and wet-AS-seed experiments.

\begin{tabular}{lrrrr}
\hline $\begin{array}{l}\text { OH exposure } \\
\left(\times 10^{11} \text { molecules } \mathrm{cm}^{-3} \mathrm{~s}\right)\end{array}$ & $\begin{array}{r}\text { [toluene] } \\
\text { reacted } \\
(\mathrm{ppb})\end{array}$ & $\begin{array}{r}\text { [toluene] } \\
(\mathrm{ppb})\end{array}$ & & \multicolumn{2}{c}{$\varepsilon^{\mathrm{a}}$} \\
\cline { 4 - 6 } & & & wet AS & dry AS \\
\hline 0.47 & 32.4 & 106.0 & 0.57 & 0.56 \\
1.66 & 84.9 & 53.5 & 0.82 & 0.82 \\
2.97 & 113.1 & 25.3 & 0.83 & 0.85 \\
4.34 & 126.9 & 11.5 & 0.83 & 0.85 \\
5.28 & 131.7 & 6.7 & 0.83 & 0.85 \\
\hline
\end{tabular}

a The volume fraction of organics.

transition for toluene-derived SOA (Bateman et al., 2015; Song et al., 2016). The toluene-derived SOA in these experiments was therefore liquid-like. The unimodal size distributions of particle numbers show the SOA formation on AS seed particles without many nucleation mode particles (Fig. S2). A CE of 1 was used for processing all AMS data since the AS seed particles were coated by liquid SOA. The adoption of this CE value was supported by the fact that the concentration of sulfate measured with the AMS varied by less than $5 \%$ of the average mass of sulfate after being coated by SOA for both wet and dry AS seeds conditions. For the quantification of SOA, the contribution from background organic aerosols was subtracted from the total organic aerosols. The ratio of SOA mass to background organic mass ranged from 7 to 59, indicating that the contribution from background organics was negligible. Aerosol particles typically pass through a silica gel diffusion dryer to remove ALW before they are measured by AMS. However, this may lead to some losses of semivolatile organics through reversible partitioning (Wong et al., 2015; Faust et al., 2017). In this study, the AS-SOA mixed-particle stream passed through and bypassed a diffusion dryer alternately before they were measured by AMS. Overall less than $8 \%$ of SOA was lost for wet and dry AS seeds after passing the diffusion dryer (Fig. S3), possibly due to reversible partitioning of the SVOCs. In this paper, the data reported are those bypassing the diffusion dryer.

A scanning mobility particle sizer (SMPS, TSI Incorporated, USA, classifier model 3082, CPC model 3775) was used to measure particle number concentrations and size distributions. Particle size ranged from 15 to $661 \mathrm{~nm}$.

To evaluate the influence of seed surface area on SOA formation, we conducted another experiment at $\mathrm{OH}$ exposure of $0.47 \times 10^{11}$ molecules $\mathrm{cm}^{-3} \mathrm{~s}$ with $50 \%$ of the seed surface area used in the wet AS experiment. The difference in SOA concentration was approximately $1 \%$ between these two experiments. Hence the $20 \%$ difference in seed surface area between wet and dry AS particles cannot account for the difference in SOA yield to be discussed below.

\subsection{Estimation of ALW content}

The ALW content of the initially dry AS was zero. However, as reactions proceed, SOA themselves can uptake water and also lower the deliquescence RH of AS, leading to water uptake by AS and some fractions of AS in the aqueous phase. The ALW contents of AS $\left(\mathrm{ALW}_{\mathrm{AS}}\right)$ and toluenederived SOA $\left(\mathrm{ALW}_{\mathrm{SOA}}\right)$ were estimated from the following equations (Kreidenweis et al., 2008):

$$
\begin{aligned}
& \mathrm{ALW}_{\mathrm{AS}}=V_{\mathrm{AS}} \kappa_{\mathrm{AS}} f \frac{\alpha_{\mathrm{w}}}{1-\alpha_{\mathrm{w}}} \rho_{\mathrm{w}}, \\
& \mathrm{ALW}_{\mathrm{SOA}}=V_{\mathrm{SOA}} \kappa_{\mathrm{SOA}} \frac{\alpha_{\mathrm{w}}}{1-\alpha_{\mathrm{w}}} \rho_{\mathrm{w}},
\end{aligned}
$$

where $V_{\mathrm{AS}}$ and $V_{\mathrm{SOA}}$ represent the volume concentrations of dry AS and SOA particles, $\kappa_{\mathrm{AS}}$ is the hygroscopicity parameter of AS particles obtained from Kreidenweis et al. (2008), $\kappa_{\mathrm{SOA}}$ is the hygroscopicity parameter of toluenederived SOA calculated using the linear correlation between $\kappa_{\mathrm{SOA}}$ and the O:C ratios of SOA proposed by Lambe et al. (2011b), the term $f$ is the fraction of AS particles that dissolved, $\alpha_{\mathrm{w}}$ is the water activity and $\rho_{\mathrm{w}}$ is the density of water $\left(1.0 \mathrm{~g} \mathrm{~cm}^{-3}\right)$. Here, $\alpha_{\mathrm{w}}$ was assumed to be equivalent to $\mathrm{RH} / 100$ for simplicity. The volume concentrations of dry AS and SOA particles were estimated from the measured mass concentration of AS and SOA assuming their respective particle densities to be 1.77 and $1.4 \mathrm{~g} \mathrm{~cm}^{-3}$ ( $\mathrm{Ng}$ et al., 2007).

For the initially wet AS seeds, all AS particles were completely aqueous and therefore $f=1$. For the initially dry AS seeds, before reactions, the AS particles were completely dry and $f=0$. After reactions, the AS particles became partially or entirely deliquesced upon the formation of toluene-derived SOA. The dissolved fraction of AS particles was regulated by the liquidus curve of the deliquescence relative humidity $(\mathrm{DRH}(\varepsilon))$ of AS particles coated with toluene-derived SOA (Smith et al., 2013):

$f=\left\{\begin{array}{ll}\frac{\varepsilon\left(1-\varepsilon_{\mathrm{D}}\right)}{\varepsilon_{\mathrm{D}}(1-\varepsilon)} & \text { for } \varepsilon<\varepsilon_{\mathrm{D}} \\ 1 & \text { for } \varepsilon \geq \varepsilon_{\mathrm{D}}\end{array}\right.$. 

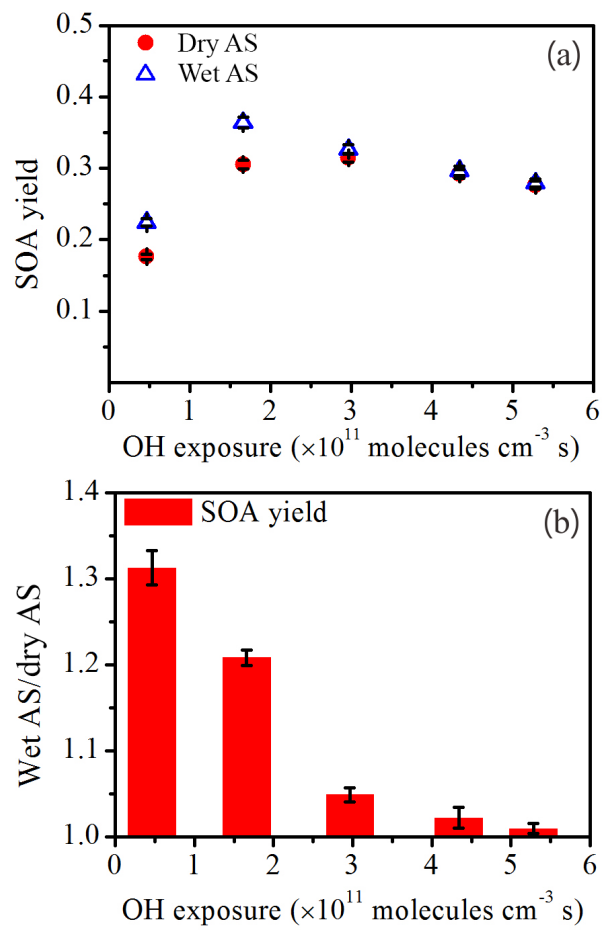

Figure 2. (a) Yield of toluene-derived SOA formed on initially wet and dry AS as a function of $\mathrm{OH}$ exposure. (b) Ratio of SOA yields on initially wet AS to those on initially dry AS as a function of $\mathrm{OH}$ exposure.

The term $\varepsilon$ is the volume fraction of SOA (Table 1). The term $\varepsilon_{\mathrm{D}}$, representing the volume fraction of organics at which the mixture of SOA and AS particles deliquesced at an RH of $68 \%$, was estimated to be 0.75 based on the liquidus curve.

\section{Results and discussion}

\subsection{SOA yields}

Figure 2a shows SOA yields from the photooxidation of toluene on initially wet and dry AS seed particles as a function of $\mathrm{OH}$ exposure. The SOA yield was calculated as the SOA mass divided by the mass of reacted toluene. The uncertainty in the SOA yields simply reflected the standard derivation when averaging the SOA mass. In both cases, SOA yields first exhibited an increase, followed by a decrease as the level of $\mathrm{OH}$ exposure increased. This trend may be due to the transition of functionalization reactions to fragmentation ones (Kroll et al., 2009; Lambe et al., 2011a). Previous oxidation flow reactor studies suggest that gas-phase chemistry dominates over heterogeneous $\mathrm{OH}$ oxidation at $\mathrm{OH}$ levels below $1.0 \times 10^{12}$ molecules $\mathrm{cm}^{-3} \mathrm{~s}$ (Ortega et al., 2016; Palm et al., 2016). In this study, the highest $\mathrm{OH}$ exposure was $5.28 \times 10^{11}$ molecules $\mathrm{cm}^{-3} \mathrm{~s}$, and heterogeneous oxidation of SOA may not play an important role in reducing the mass of SOA, although we cannot exclude that it plays a role. In addition, glyoxal is an important oxidation product of toluene (Kamens et al., 2011). The reactive uptake of glyoxal has been demonstrated to enhance rather than reduce the SOA mass (Liggio et al., 2005a). The SOA yields for dry and wet AS seeds were $0.18-0.31$ and $0.22-0.36$, respectively, significantly higher than the value of 0.0059 observed in an oxidation flow reactor under comparable conditions (Faust et al., 2017) and the value of 0.09 obtained in another PAM chamber at $30 \%$ RH in the absence of seed particles (Kang et al., 2007). Faust et al. (2017) attributed their significantly lower yields than typical literature values of 0.09-0.30 (Lambe et al., 2011a; Ng et al., 2007) to the wall loss of particles and the fragmentation of organics in their flow reactor. On the other hand, the SOA yields we obtained are lower than the values of 0.30-0.37 from smog chamber experiments conducted at a similar temperature, SOA mass loading and $\mathrm{OH}$ exposure but a lower RH with dry AS seeds (Ng et al., 2007; Hildebrandt et al., 2009). Note that the wall loss of particles was not corrected in this study, so the SOA yields may be underestimated. As wet and dry AS seeds in this study had similar particle number size distributions, the wall loss of particles would not affect the comparison of SOA yield between wet and dry AS seeds.

As shown in Fig. 2a, a higher SOA yield was observed for wet AS seeds than for dry AS seeds at the same $\mathrm{OH}$ exposure, and the difference in SOA yield decreased as the $\mathrm{OH}$ exposure increased. The ratio of SOA yields on wet AS seeds to those on dry AS seeds, the relative SOA yield, was $1.31 \pm 0.02$ at an $\mathrm{OH}$ exposure of $0.47 \times 10^{11}$ molecules $\mathrm{cm}^{-3} \mathrm{~s}$ but decreased to $1.01 \pm 0.01$ when the $\mathrm{OH}$ exposure was increased to $5.28 \times 10^{11}$ molecules $\mathrm{cm}^{-3} \mathrm{~s}$ (Fig. 2b). These ratios are comparable to the $1.19 \pm 0.05$ observed by Faust et al. (2017) at an $\mathrm{OH}$ exposure of approximately $2.0 \times 10^{11}$ molecules $\mathrm{cm}^{-3} \mathrm{~s}$.

The formation of SOA on initially dry AS particles may alter the deliquescence relative humidity (DRH) of AS particles. Smith et al. (2013) found that, when AS particles were coated with toluene-derived SOA, the DRH decreased from 80 to $58 \%$ as the organic volume fraction increased from 0 to 0.8 . Therefore, coating AS particles with toluene-derived SOA can change the physical state of initially dry AS seeds and increase the content of $\mathrm{ALW}_{\mathrm{AS} \text {, dry }}$. As shown in Fig. 3a, after reactions, the mass concentrations of $\mathrm{ALW}_{\text {tot }}\left(=\mathrm{ALW}_{\mathrm{SOA}}+\mathrm{ALW}_{\mathrm{AS}}\right)$ and $\mathrm{ALW}_{\mathrm{SOA}}$ increased for both wet and dry seeds as the $\mathrm{OH}$ exposure increased. The uncertainties for $\mathrm{ALW}_{\mathrm{SOA}}$ and $\mathrm{ALW}_{\mathrm{AS}}$ were $22 \%$ and less than $3 \%$, respectively. They reflect the uncertainties in $\kappa$ and volume concentrations of AS and SOA. The increase in $\mathrm{ALW}_{\text {tot, wet }}$ was due to the increase in $\mathrm{ALW}_{\text {SOA, wet }}$, while the increase in $\mathrm{ALW}_{\text {tot, dry }}$ was driven by the increase in $\mathrm{ALW}_{\mathrm{AS}}$, dry at lower $\mathrm{OH}$ exposure and by $\mathrm{ALW}_{\mathrm{SOA}}$, dry at higher $\mathrm{OH}$ exposures. At $\mathrm{OH}$ exposure of $0.47 \times 10^{11}$ molecules $^{-3} \mathrm{~s}, \mathrm{ALW}_{\mathrm{AS}}$, dry increased from 0 to $6.2 \mu \mathrm{g} \mathrm{m}^{-3}$ after reactions due to the partial deliquescence 


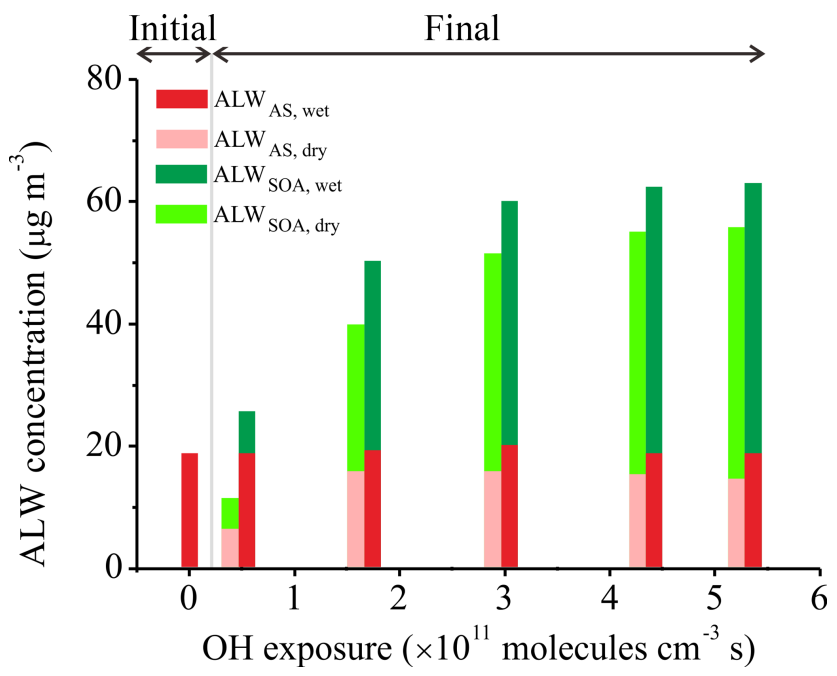

Figure 3. Mass concentration of ALW uptake by AS and toluenederived SOA before (initial) and after reactions (final) for both initially wet and dry AS seeds. Adjoining bars for initially wet and dry seeds have same $\mathrm{OH}$ exposures.

( $f=0.43$ ) of the originally dry AS particles after SOA formation. The difference in $\mathrm{ALW}_{\mathrm{AS} \text {, dry }}$ and $\mathrm{ALW}_{\mathrm{AS}}$, wet narrowed, and the ALW total of initially dry AS seeds partially resembled those of the wet ones. At $\mathrm{OH}$ exposure between $1.66 \times 10^{11}$ and $5.28 \times 10^{11}$ molecules $\mathrm{cm}^{-3} \mathrm{~s}$, the total final organic volume fraction increased to approximately 0.8 , and the initially dry AS particles entirely deliquesced after reactions. Based on the reported SOA yield, initial toluene concentration, $\mathrm{OH}$ exposure and assumed concentrations of AS seeds $\left(\sim 10-40 \mu \mathrm{g} \mathrm{m}^{-3}\right)$ in Faust et al. (2017), we estimated that an upper limit of $48 \%$ of the initially dry AS seeds deliquesced in their study. Similar to this study, SOA coatings on seed particles may change the physical state of initially dry seeds and lower the difference of SOA yields between initially dry- and wet-seed experiments.

The hydrophilic products can partition more readily into initially wet AS seeds than dry seeds and partially account for the difference in SOA yields. For example, as one of the important oxidation products, glyoxal was estimated to have an effective Henry's law constant of $4.52 \times 10^{8} \mathrm{~m} \mathrm{~atm}^{-1}$ for our initially wet AS seeds due to the "salting-in" effect (Kampf et al., 2013), approximately 3 orders of magnitude higher than that in pure water (Ip et al., 2009). The uptake rate constant of glyoxal can be calculated as $(\gamma v A) / 4$, where $\gamma$ is the uptake coefficient, $v$ is the gas-phase velocity of glyoxal and $A$ is the total surface area of AS seeds. The uptake rate constant is $4.5 \times 10^{-4} \mathrm{~s}^{-1}$ for initially wet seeds with $\gamma=2.4 \times 10^{-3}$ estimated from glyoxal uptake in AS seeds at $68 \% \mathrm{RH}$ (Liggio et al., 2005b). The average gas-phase glyoxal concentration was modeled to be $4.3 \mathrm{ppb}$ at $\mathrm{OH}$ exposure of $0.47 \times 10^{11}$ molecules $\mathrm{cm}^{-3} \mathrm{~s}$ using the Master Chemical Mechanism v 3.3.1 (Jenkin et al., 2003; Bloss et al., 2005), which would result in approximately $1.6 \mu \mathrm{g} \mathrm{m}^{-3}$ of glyoxal in the particle phase for initially wet AS seeds. If the particle-phase concentration of glyoxal was assumed to be 0 for initially dry AS seeds, the enhanced partitioning of glyoxal alone would account for $24.5 \%$ of the mass difference of SOA. Note that other hydrophilic products were not included in this calculation. This analysis suggests that the enhanced partitioning of hydrophilic products may play an important role in the difference of SOA yields at low $\mathrm{OH}$ exposures. As discussed above, the initially dry AS seeds approached wet seeds and reduced the differences between wet and dry SOA yields at high $\mathrm{OH}$ exposures.

\subsection{Chemical composition of SOA}

Figure 4 shows the high-resolution mass spectra of SOA for initially wet and dry AS seeds at $\mathrm{OH}$ exposures of $0.47 \times 10^{11}$ and $5.28 \times 10^{11}$ molecules $\mathrm{cm}^{-3} \mathrm{~s}$. For both types of AS seeds, at an $\mathrm{OH}$ exposure of $0.47 \times 10^{11}$ molecules $\mathrm{cm}^{-3} \mathrm{~s}$, the most prominent peaks were $\mathrm{m} / z 29$ and 43, followed by $\mathrm{m} / z 28$ and $44 . \mathrm{m} / z 29$ was dominated by ion $\mathrm{CHO}^{+}$, a tracer for alcohols and aldehydes (Lee et al., 2012). The $m / z 28$ and 44 signals, respectively dominated by $\mathrm{CO}^{+}$and $\mathrm{CO}_{2}^{+}$, are tracers for organic acids ( $\mathrm{Ng}$ et al., 2010). At the $\mathrm{OH}$ exposure of $5.28 \times 10^{11}$ molecules $\mathrm{cm}^{-3} \mathrm{~s}$, the dominant peaks were $m / z 8$ and 44 , followed by $m / z 29$ and 43. The increase of mass fractions of the oxygen-containing ions in the SOA mass spectra at a relatively high $\mathrm{OH}$ exposure suggests the formation of more oxidized organic aerosols. On the basis of the mass fraction of ions, Fig. S4 shows that, as $\mathrm{OH}$ exposure increased, the difference (wet minus dry) in the spectra of toluene-derived SOA changed from positive in $m / z 29\left(\mathrm{CHO}^{+}\right)$and $m / z 43\left(\mathrm{C}_{2} \mathrm{H}_{3} \mathrm{O}^{+}\right)$to $\mathrm{m} / z 28$ $\left(\mathrm{CO}^{+}\right)$and $m / z 44\left(\mathrm{CO}_{2}^{+}\right)$. The increase in $\mathrm{OH}$ exposure resulted in a change from more alcohols or aldehydes to more organic acids in the wet-seeded case when compared to the dry-seeded case.

Fragments derived from the AMS data have been extensively used to infer the bulk compositions and evolution of organic aerosols (Zhang et al., 2005; Ng et al., 2010; Heald et al., 2010). Here we used the approach of $\mathrm{Ng}$ et al. (2010) and plotted the fractions of the total organic signal at $m / z 43$ $\left(f_{43}\right)$ vs. $m / z 44\left(f_{44}\right)$ as well as the triangle based on the analysis of ambient AMS data (Fig. 5). Ng et al. (2010) proposed that aging would cause $f_{43}$ and $f_{44}$ to converge toward the triangle apex $\left(f_{43}=0.02, f_{44}=0.30\right)$. For both wet and dry AS seeds, $f_{43}$ first increased and then decreased with the increase of $\mathrm{OH}$ exposure, while $f_{44}$ increased all the time. This reversing trend of $f_{43}$ was the result of the increase and subsequent decrease in $\mathrm{C}_{2} \mathrm{H}_{3} \mathrm{O}^{+}$(Fig. S5), an indicator of products containing carbonyl functional groups. The $f_{43}-$ $f_{44}$ plot supports our earlier assertion that, as $\mathrm{OH}$ exposure increased, the reaction products changed from an earliergeneration dominated by products containing carbonyl func- 

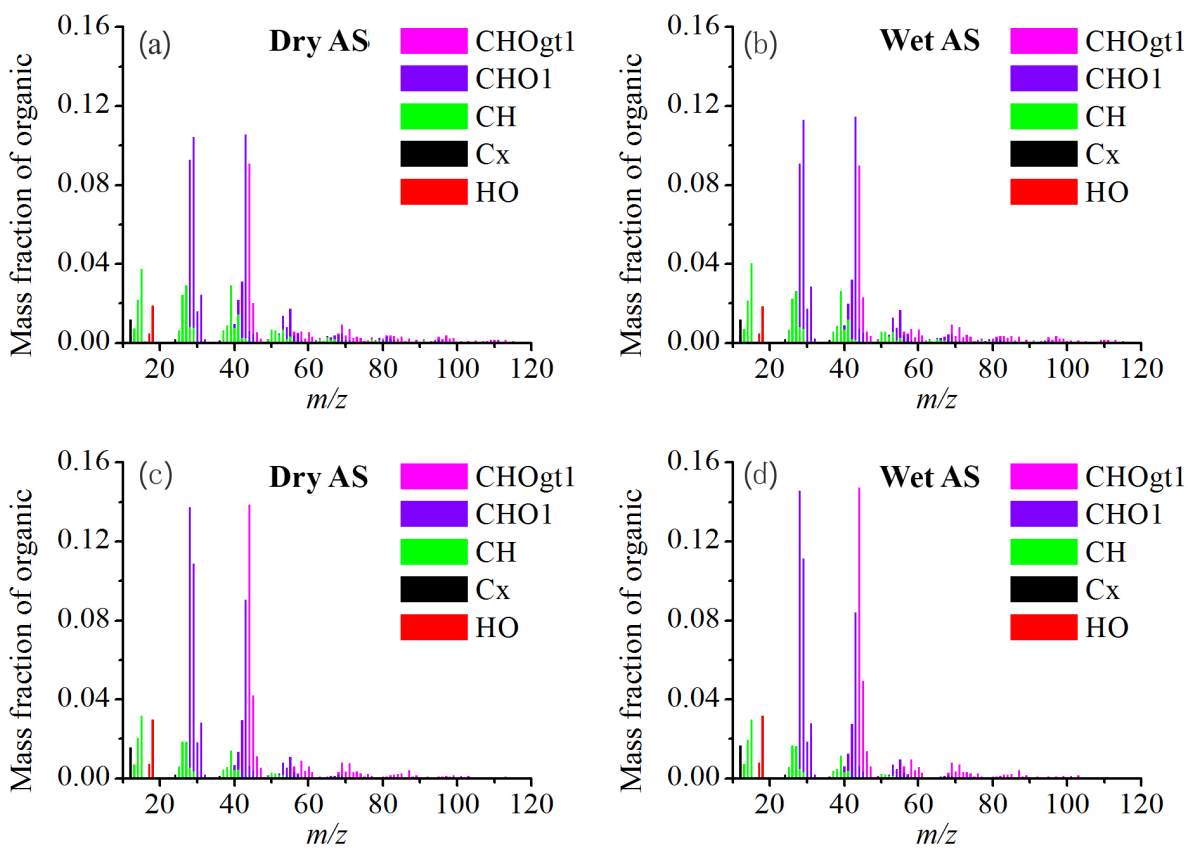

Figure 4. High-resolution mass spectra of toluene-derived SOA on initially wet and dry AS at an OH exposure of (a, b) $0.47 \times 10^{11}$ molecules $\mathrm{cm}^{-3} \mathrm{~s}$ and $(\mathbf{c}, \mathbf{d}) 5.28 \times 10^{11}$ molecules $\mathrm{cm}^{-3} \mathrm{~s}$.

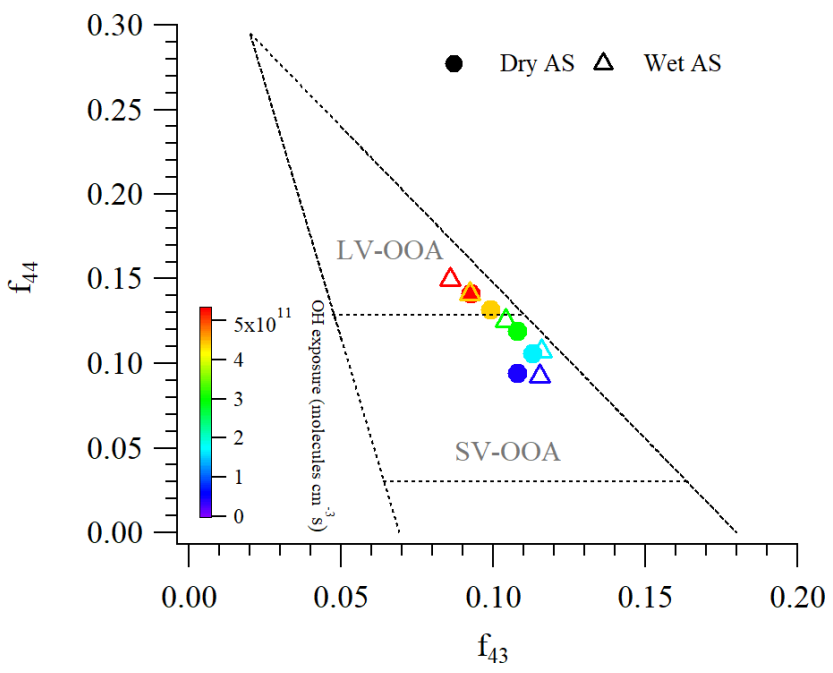

Figure 5. Fractions of total organic signal at $m / z \quad 43\left(f_{43}\right)$ vs. $m / z 44\left(f_{44}\right)$ from SOA data obtained in this study together with the triangle plot of $\mathrm{Ng}$ et al. (2010). Ambient SV-OOA and LV-OOA regions are adapted from $\mathrm{Ng}$ et al. (2010). Data are colored according to the $\mathrm{OH}$ exposure.

tional groups to a later-generation dominated by products containing acidic functional groups. It was also observed for SOA formed from other precursors such as alkanes and naphthalene (Lambe et al., 2011b). Before the decrease in $f_{43}$, SOA formed on wet AS seeds had higher $f_{43}$ and similar $f_{44}$ to SOA formed on dry AS seeds at the same $\mathrm{OH}$ exposure. As $\mathrm{OH}$ exposure increased, SOA formed on wet AS seeds had higher $f_{44}$ and lower $f_{43}$ than SOA formed on dry AS seeds. In addition, as $\mathrm{OH}$ exposure increased, SOA formed on wet AS seeds initially had more earlier-generation products but later had more acidic later-generation products than SOA formed on dry AS seeds, likely related to the enhanced partitioning of these products on initially wet AS seeds and/or enhanced uptake of water-soluble gases through aqueous-phase reactions.

Figure 6 shows the changes in $\mathrm{H}: \mathrm{C}$ and $\mathrm{O}: \mathrm{C}$ ratios as a function of $\mathrm{OH}$ exposure in a Van Krevelen diagram (Heald et al., 2010). The standard deviations for $\mathrm{H}: \mathrm{C}$ and $\mathrm{O}: \mathrm{C}$ values, determined for the steady-state periods, were all less than 0.01 . The $\mathrm{O}: \mathrm{C}$ ratios for dry and wet AS seeds were in the ranges of $0.59-0.89$ and $0.63-0.95$, respectively. At the same $\mathrm{OH}$ exposure, SOA on wet AS seeds had both higher $\mathrm{O}: \mathrm{C}$ ratios and an estimated average carbon oxidation state $\left(\mathrm{OS}_{\mathrm{C}}\right)\left(\mathrm{OS}_{\mathrm{C}} \approx 2 \times \mathrm{O}: \mathrm{C}-\mathrm{H}: \mathrm{C}\right)$ (Kroll et al., 2011) than dry AS seeds had. Figure 6 also shows some of the identified SOA products from the photooxidation of toluene (Bloss et al., 2005; Hamilton et al., 2005; Sato et al., 2007). The elevated $\mathrm{OS}_{\mathrm{C}}$ (exceeding 0.5) could only be due to the formation of highly oxgenerated small acids such as pyruvic acid $\left(\mathrm{OS}_{\mathrm{C}}=0.67\right)$, glycolic acid $\left(\mathrm{OS}_{\mathrm{C}}=1\right)$, formic acid $\left(\mathrm{OS}_{\mathrm{C}}=2\right)$, oxalic acid $\left(\mathrm{OS}_{\mathrm{C}}=3\right)$, malonic acid $\left(\mathrm{OS}_{\mathrm{C}}=\right.$ $1.33)$ and glyoxylic acid $\left(\mathrm{OS}_{\mathrm{C}}=2\right)$. Small acids may be important products of toluene-derived SOA at high $\mathrm{OH}$ exposures. Fisseha et al. (2004) found that small organic acids accounted for $20-45 \%$ of SOA from the photooxidation of 1,3,5-trimethylbenzene. The higher $\mathrm{OS}_{\mathrm{C}}$ at high $\mathrm{OH}$ exposures for wet AS seeds might suggest that these small acids 


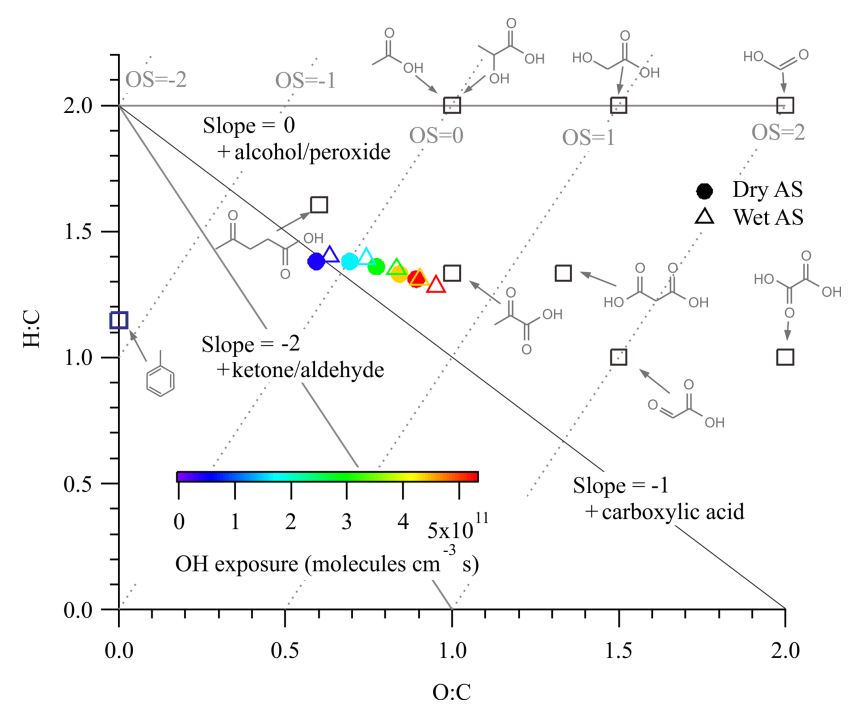

Figure 6. Van Krevelen diagram of SOA derived from the photooxidation of toluene on initially wet and dry AS seed particles. SOA data are colored according to the $\mathrm{OH}$ exposure. Products identified in toluene-derived SOA are shown in boxes (Bloss et al., 2005; Hamilton et al., 2005; Sato et al., 2007). Average carbon oxidation states from Kroll et al. (2011) and functionalization slopes from Heald et al. (2010) are shown for reference.

were more abundant, likely due to their enhanced retention in the presence of ALW and/or the more efficient uptake of $\mathrm{OH}$ radicals by wet AS seeds and further oxidation reactions in the aqueous phase (Ruehl et al., 2013).

We evaluate whether enhanced uptake of $\mathrm{OH}$ radicals on initially wet AS seeds could explain the difference in oxygen contents, following the method of DeCarlo et al. (2008). We calculated $R$, the ratio of the difference in oxygen of OA between the initially wet and dry AS seed particles to the difference in the total number of OH collisions with OA at different $\mathrm{OH}$ exposures. To obtain $R$, the uptake coefficient $(\gamma)$ of $\mathrm{OH}$ radicals was assumed to be 1 and 0.1 or 0.8 (lower or upper limit, respectively) for initially wet and dry AS seed particles, respectively (George and Abbatt, 2010). Note that as SOA formation takes place the initially dry AS can become wet and the difference in $\gamma$ between initially wet and dry seeds is reduced, especially at higher $\mathrm{OH}$ exposures. We also assumed that each collision of $\mathrm{OH}$ with $\mathrm{OA}$ resulted in the addition of one oxygen atom to SOA. A value of $R$ smaller than unity qualitatively indicates that the uptake of $\mathrm{OH}$ radicals can potentially explain the differences in oxygen contents in the dry and wet experiments. Figure S6 shows that $\mathrm{R}$ is larger than unity at low $\mathrm{OH}$ exposures and smaller than unity at high $\mathrm{OH}$ exposures. This analysis suggests that the enhanced $\mathrm{OH}$ uptake may contribute to the difference in oxygen contents between dry and wet cases at higher $\mathrm{OH}$ exposures. At low $\mathrm{OH}$ exposures, the enhanced gas-particle partitioning may dominate the difference.
The change in the slope of $\mathrm{H}: \mathrm{C}$ vs. $\mathrm{O}: \mathrm{C}$ is consistent with the earlier analysis that the mechanism of SOA formation changed from functionalization dominated by the addition of alcohol/peroxide (Heald et al., 2010; Ng et al., 2011) at low exposures to the addition of both acid and alcohol/peroxide functional groups without fragmentation, and/or the addition of acid groups with fragmentation at high exposures.

\subsection{Atmospheric implications}

In this work, yields and composition of SOA formed from the photooxidation of toluene on initially wet and dry AS seeds were compared over a wide range of $\mathrm{OH}$ exposures, covering the transition from functionalization reactions to fragmentation reactions. We found that the ratio of SOA yield on wet AS seeds to that on dry AS seeds decreased from 1.31 to 1.01 as the $\mathrm{OH}$ exposure increased from $0.47 \times 10^{11}$ to $5.28 \times 10^{11}$ molecules $\mathrm{cm}^{-3} \mathrm{~s}$. This decrease coincides with the decrease of differences in ALW between the wet and dry cases, which may be due to water uptake by SOA as well as the early deliquescence of dry AS particles as a result of SOA formation. Hence, the SOA yield and ALW of the initially dry AS seeds approached those of the initially wet AS seeds as $\mathrm{OH}$ exposure and ALW increased.

In addition to relatively higher SOA yields, higher $\mathrm{O}: \mathrm{C}$ and $\mathrm{OS}_{\mathrm{c}}$ of SOA derived from the photooxidation of toluene were also observed on initially wet AS seeds. Particularly, the $\mathrm{O}: \mathrm{C}$ in the presence of initially wet AS seeds could be as high as 0.95. Chen et al. (2015) observed large gaps between laboratory and ambient measured $\mathrm{O}: \mathrm{C}$ of $\mathrm{OA}$ and suggested that $\mathrm{OA}$ having a high $\mathrm{O}: \mathrm{C}(>0.6)$ was required to bridge these gaps. The multiphase oxidation of toluene in the presence of wet aerosols may be a pathway to contribute to this gap. However, the relative importance of such chemistry to the evolution of ambient OA remains unclear.

Our results suggest that dry seeds would quickly turn to at least partially deliquesced particles upon SOA formation under moderate RH conditions. We only studied the photooxidation of toluene in the absence of $\mathrm{NO}_{x}$ as it is still a challenge to study high-NO chemistry in oxidation flow reactors without using atmospherically irrelevantly high concentrations of $\mathrm{NO}_{x}$ (Peng and Jimenez, 2017). However, the ALW may also be important to SOA formation under high$\mathrm{NO}_{x}$ conditions that preferentially form highly water-soluble products (Ervens et al., 2011). Since ambient RH is rarely at such low values that inorganic particles remain dry even after SOA formation, more laboratory and field studies are needed to elucidate the formation and evolution of $\mathrm{OA}$ under various $\mathrm{NO}_{x}$ conditions at moderate $\mathrm{RH}$.

Data availability. The data used in this publication are available to the community and can be accessed by request to the corresponding author. 


\section{The Supplement related to this article is available online at https://doi.org/10.5194/acp-18-5677-2018-supplement.}

Competing interests. The authors declare that they have no conflict of interest.

Acknowledgements. The work described in this paper was sponsored by the Science Technology and Innovation Committee of Shenzhen Municipality (project no. JCYJ20160401095857424). Zijun Li and ManNin Chan are supported by a Direct Grant for Research (4053159), The Chinese University of Hong Kong and a Research Grants Council grant (RGC 2191111). Chak K. Chan would like to thank the Hong Kong University of Science and Technology for the use of the AMS.

Edited by: Robert McLaren

Reviewed by: two anonymous referees

\section{References}

Aiken, A. C., DeCarlo, P. F., and Jimenez, J. L.: Elemental Analysis of Organic Species with Electron Ionization HighResolution Mass Spectrometry, Anal. Chem., 79, 8350-8358, https://doi.org/10.1021/ac071150w, 2007.

Aiken, A. C., DeCarlo, P. F., Kroll, J. H., Worsnop, D. R., Huffman, J. A., Docherty, K. S., Ulbrich, I. M., Mohr, C., Kimmel, J. R., Sueper, D., Sun, Y., Zhang, Q., Trimborn, A., Northway, M., Ziemann, P. J., Canagaratna, M. R., Onasch, T. B., Alfarra, M. R., Prevot, A. S. H., Dommen, J., Duplissy, J., Metzger, A., Baltensperger, U., and Jimenez, J. L.: O/C and OM/OC Ratios of Primary, Secondary, and Ambient Organic Aerosols with High-Resolution Time-of-Flight Aerosol Mass Spectrometry, Environ. Sci. Technol., 42, 4478-4485, https://doi.org/10.1021/es703009q, 2008.

Atkinson, R. and Arey, J.: Atmospheric Degradation of Volatile Organic Compounds, Chem. Rev., 103, 4605-4638, https://doi.org/10.1021/cr0206420, 2003.

Balkanski, Y. J., Jacob, D. J., Gardner, G. M., Graustein, W. C., and Turekian, K. K.: Transport and residence times of tropospheric aerosols inferred from a global three-dimensional simulation of 210Pb, J. Geophys. Res.-Atmos., 98, 20573-20586, https://doi.org/10.1029/93JD02456, 1993.

Barsanti, K. C., Carlton, A. G., and Chung, S. H.: Analyzing experimental data and model parameters: implications for predictions of SOA using chemical transport models, Atmos. Chem. Phys., 13, 12073-12088, https://doi.org/10.5194/acp-13-120732013, 2013.

Bateman, A. P., Bertram, A. K., and Martin, S. T.: Hygroscopic Influence on the Semisolid-to-Liquid Transition of Secondary Organic Materials, J. Phys. Chem. A, 119, 4386-4395, https://doi.org/10.1021/jp508521c, 2015.

Bloss, C., Wagner, V., Jenkin, M. E., Volkamer, R., Bloss, W. J., Lee, J. D., Heard, D. E., Wirtz, K., Martin-Reviejo, M., Rea, G., Wenger, J. C., and Pilling, M. J.: Development of a detailed chemical mechanism (MCMv3.1) for the atmospheric oxidation of aromatic hydrocarbons, Atmos. Chem. Phys., 5, 641-664, https://doi.org/10.5194/acp-5-641-2005, 2005.

Calvert, J. G., Atkinson, R., Becker, K. H., Kamens, R. M., Seinfeld, J. H., Wallington, T. H., and Yarwood, G.: The Mechanisms of Atmospheric Oxidation of the Aromatic Hydrocarbons, Oxford University Press, New York, 556 p., 2002.

Chan, C. K., Flagan, R. C., and Seinfeld, J. H.: Water activities of $\mathrm{NH}_{4} \mathrm{NO}_{3} /\left(\mathrm{NH}_{4}\right)_{2} \mathrm{SO}_{4}$ solutions, Atmos. Environ., 26, 16611673, https://doi.org/10.1016/0960-1686(92)90065-S, 1992.

Chen, Q., Heald, C. L., Jimenez, J. L., Canagaratna, M. R., Zhang, Q., He, L.-Y., Huang, X.-F., Campuzano-Jost, P., Palm, B. B., Poulain, L., Kuwata, M., Martin, S. T., Abbatt, J. P. D., Lee, A. K. Y., and Liggio, J.: Elemental composition of organic aerosol: The gap between ambient and laboratory measurements, Geophys. Res. Lett., 42, 2015GL063693, https://doi.org/10.1002/2015GL063693, 2015.

DeCarlo, P. F., Kimmel, J. R., Trimborn, A., Northway, M. J., Jayne, J. T., Aiken, A. C., Gonin, M., Fuhrer, K., Horvath, T., Docherty, K. S., Worsnop, D. R., and Jimenez, J. L.: Field-Deployable, High-Resolution, Time-ofFlight Aerosol Mass Spectrometer, Anal. Chem., 78, 8281-8289, https://doi.org/10.1021/ac061249n, 2006.

DeCarlo, P. F., Dunlea, E. J., Kimmel, J. R., Aiken, A. C., Sueper, D., Crounse, J., Wennberg, P. O., Emmons, L., Shinozuka, Y., Clarke, A., Zhou, J., Tomlinson, J., Collins, D. R., Knapp, D., Weinheimer, A. J., Montzka, D. D., Campos, T., and Jimenez, J. L.: Fast airborne aerosol size and chemistry measurements above Mexico City and Central Mexico during the MILAGRO campaign, Atmos. Chem. Phys., 8, 4027-4048, https://doi.org/10.5194/acp-8-4027-2008, 2008.

de Gouw, J. A., Middlebrook, A. M., Warneke, C., Goldan, P. D., Kuster, W. C., Roberts, J. M., Fehsenfeld, F. C., Worsnop, D. R., Canagaratna, M. R., Pszenny, A. A. P., Keene, W. C., Marchewka, M., Bertman, S. B., and Bates, T. S.: Budget of organic carbon in a polluted atmosphere: Results from the New England Air Quality Study in 2002, J. Geophys. Res.-Atmos., 110, D16305, https://doi.org/10.1029/2004JD005623, 2005.

Ding, X., Wang, X.-M., Gao, B., Fu, X.-X., He, Q.-F., Zhao, X.-Y., Yu, J.-Z., and Zheng, M.: Tracer-based estimation of secondary organic carbon in the Pearl River Delta, south China, J. Geophys. Res.-Atmos., 117, D05313, https://doi.org/10.1029/2011JD016596, 2012.

Donahue, N. M., Robinson, A. L., Stanier, C. O., and Pandis, S. N.: Coupled Partitioning, Dilution, and Chemical Aging of Semivolatile Organics, Environ. Sci. Technol., 40, 2635-2643, https://doi.org/10.1021/es052297c, 2006.

Edney, E. O., Driscoll, D. J., Speer, R. E., Weathers, W. S., Kleindienst, T. E., Li, W., and Smith, D. F.: Impact of aerosol liquid water on secondary organic aerosol yields of irradiated toluene/propylene/NOx/(NH4)2SO4/air mixtures, Atmos. Environ., 34, 3907-3919, 2000.

Ervens, B., Turpin, B. J., and Weber, R. J.: Secondary organic aerosol formation in cloud droplets and aqueous particles (aqSOA): a review of laboratory, field and model studies, Atmos. Chem. Phys., 11, 11069-11102, https://doi.org/10.5194/acp-1111069-2011, 2011.

Faust, J. A., Wong, J. P. S., Lee, A. K. Y., and Abbatt, J. P. D.: Role of Aerosol Liquid Water in Secondary Organic Aerosol Forma- 
tion from Volatile Organic Compounds, Environ. Sci. Technol., 51, 1405-1413, https://doi.org/10.1021/acs.est.6b04700, 2017.

Fisseha, R., Dommen, J., Sax, M., Paulsen, D., Kalberer, M., Maurer, R., Höfler, F., Weingartner, E., and Baltensperger, U.: Identification of Organic Acids in Secondary Organic Aerosol and the Corresponding Gas Phase from Chamber Experiments, Anal. Chem., 76, 6535-6540, https://doi.org/10.1021/ac048975f, 2004.

George, I. J. and Abbatt, J. P. D.: Heterogeneous oxidation of atmospheric aerosol particles by gas-phase radicals, Nat. Chem., 2, 713-722, 2010.

Guo, H., Xu, L., Bougiatioti, A., Cerully, K. M., Capps, S. L., Hite Jr., J. R., Carlton, A. G., Lee, S.-H., Bergin, M. H., Ng, N. L., Nenes, A., and Weber, R. J.: Fine-particle water and $\mathrm{pH}$ in the southeastern United States, Atmos. Chem. Phys., 15, 5211-5228, https://doi.org/10.5194/acp-15-5211-2015, 2015.

Hallquist, M., Wenger, J. C., Baltensperger, U., Rudich, Y., Simpson, D., Claeys, M., Dommen, J., Donahue, N. M., George, C., Goldstein, A. H., Hamilton, J. F., Herrmann, H., Hoffmann, T., Iinuma, Y., Jang, M., Jenkin, M. E., Jimenez, J. L., Kiendler-Scharr, A., Maenhaut, W., McFiggans, G., Mentel, Th. F., Monod, A., Prévôt, A. S. H., Seinfeld, J. H., Surratt, J. D., Szmigielski, R., and Wildt, J.: The formation, properties and impact of secondary organic aerosol: current and emerging issues, Atmos. Chem. Phys., 9, 5155-5236, https://doi.org/10.5194/acp9-5155-2009, 2009.

Hamilton, J. F., Webb, P. J., Lewis, A. C., and Reviejo, M. M.: Quantifying small molecules in secondary organic aerosol formed during the photo-oxidation of toluene with hydroxyl radicals, Atmos. Environ., 39, 7263-7275, https://doi.org/10.1016/j.atmosenv.2005.09.006, 2005.

Hayes, P. L., Carlton, A. G., Baker, K. R., Ahmadov, R., Washenfelder, R. A., Alvarez, S., Rappenglück, B., Gilman, J. B., Kuster, W. C., de Gouw, J. A., Zotter, P., Prévôt, A. S. H., Szidat, S., Kleindienst, T. E., Offenberg, J. H., Ma, P. K., and Jimenez, J. L.: Modeling the formation and aging of secondary organic aerosols in Los Angeles during CalNex 2010, Atmos. Chem. Phys., 15, 5773-5801, https://doi.org/10.5194/acp-15-5773-2015, 2015.

Heald, C. L., Kroll, J. H., Jimenez, J. L., Docherty, K. S., DeCarlo, P. F., Aiken, A. C., Chen, Q., Martin, S. T., Farmer, D. K., and Artaxo, P.: A simplified description of the evolution of organic aerosol composition in the atmosphere, Geophys. Res. Lett., 37, L08803, https://doi.org/10.1029/2010g1042737, 2010.

Hennigan, C. J., Bergin, M. H., Dibb, J. E., and Weber, R. J.: Enhanced secondary organic aerosol formation due to water uptake by fine particles, Geophys. Res. Lett., 35, L18801, https://doi.org/10.1029/2008GL035046, 2008.

Hildebrandt, L., Donahue, N. M., and Pandis, S. N.: High formation of secondary organic aerosol from the photooxidation of toluene, Atmos. Chem. Phys., 9, 2973-2986, https://doi.org/10.5194/acp-9-2973-2009, 2009.

Hodzic, A., Jimenez, J. L., Madronich, S., Canagaratna, M. R., DeCarlo, P. F., Kleinman, L., and Fast, J.: Modeling organic aerosols in a megacity: potential contribution of semi-volatile and intermediate volatility primary organic compounds to secondary organic aerosol formation, Atmos. Chem. Phys., 10, 5491-5514, https://doi.org/10.5194/acp-10-5491-2010, 2010.

Huang, D. D., Zhang, X., Dalleska, N. F., Lignell, H., Coggon, M. M., Chan, C.-M., Flagan, R. C., Seinfeld, J. H., and
Chan, C. K.: A note on the effects of inorganic seed aerosol on the oxidation state of secondary organic aerosol $-\alpha$-Pinene ozonolysis, J. Geophys. Res.-Atmos., 121, 2016JD025999, https://doi.org/10.1002/2016JD025999, 2016.

Ip, H. S. S., Huang, X. H. H., and Yu, J. Z.: Effective Henry's law constants of glyoxal, glyoxylic acid, and glycolic acid, Geophys. Res. Lett., 36, L01802, https://doi.org/10.1029/2008GL036212, 2009.

Jenkin, M. E., Saunders, S. M., Wagner, V., and Pilling, M. J.: Protocol for the development of the Master Chemical Mechanism, MCM v3 (Part B): tropospheric degradation of aromatic volatile organic compounds, Atmos. Chem. Phys., 3, 181-193, https://doi.org/10.5194/acp-3-181-2003, 2003.

Kamens, R. M., Zhang, H. F., Chen, E. H., Zhou, Y., Parikh, H. M., Wilson, R. L., Galloway, K. E., and Rosen, E. P.: Secondary organic aerosol formation from toluene in an atmospheric hydrocarbon mixture: Water and particle seed effects, Atmos. Environ., 45, 2324-2334, https://doi.org/10.1016/j.atmosenv.2010.11.007, 2011.

Kampf, C. J., Waxman, E. M., Slowik, J. G., Dommen, J., Pfaffenberger, L., Praplan, A. P., Prévôt, A. S. H., Baltensperger, U., Hoffmann, T., and Volkamer, R.: Effective Henry's Law Partitioning and the Salting Constant of Glyoxal in Aerosols Containing Sulfate, Environ. Sci. Technol., 47, 4236-4244, https://doi.org/10.1021/es400083d, 2013.

Kang, E., Root, M. J., Toohey, D. W., and Brune, W. H.: Introducing the concept of Potential Aerosol Mass (PAM), Atmos. Chem. Phys., 7, 5727-5744, https://doi.org/10.5194/acp-7-5727-2007, 2007.

Kang, E., Toohey, D. W., and Brune, W. H.: Dependence of SOA oxidation on organic aerosol mass concentration and $\mathrm{OH}$ exposure: experimental PAM chamber studies, Atmos. Chem. Phys., 11, 1837-1852, https://doi.org/10.5194/acp-11-1837-2011, 2011.

Krechmer, J. E., Pagonis, D., Ziemann, P. J., and Jimenez, J. L.: Quantification of Gas-Wall Partitioning in Teflon Environmental Chambers Using Rapid Bursts of Low-Volatility Oxidized Species Generated in Situ, Environ. Sci. Technol., 50, 57575765, https://doi.org/10.1021/acs.est.6b00606, 2016.

Kreidenweis, S. M., Petters, M. D., and DeMott, P. J.: Singleparameter estimates of aerosol water content, Environ. Res. Lett., 3, 035002, https://doi.org/10.1088/1748-9326/3/3/035002, 2008.

Kroll, J. H., Smith, J. D., Che, D. L., Kessler, S. H., Worsnop, D. R., and Wilson, K. R.: Measurement of fragmentation and functionalization pathways in the heterogeneous oxidation of oxidized organic aerosol, Phys. Chem. Chem. Phys., 11, 8005-8014, https://doi.org/10.1039/B905289E, 2009.

Kroll, J. H., Donahue, N. M., Jimenez, J. L., Kessler, S. H., Canagaratna, M. R., Wilson, K. R., Altieri, K. E., Mazzoleni, L. R., Wozniak, A. S., Bluhm, H., Mysak, E. R., Smith, J. D., Kolb, C. E., and Worsnop, D. R.: Carbon oxidation state as a metric for describing the chemistry of atmospheric organic aerosol, Nat. Chem., 3, 133-139, 2011.

Lambe, A. T., Ahern, A. T., Williams, L. R., Slowik, J. G., Wong, J. P. S., Abbatt, J. P. D., Brune, W. H., Ng, N. L., Wright, J. P., Croasdale, D. R., Worsnop, D. R., Davidovits, P., and Onasch, T. B.: Characterization of aerosol photooxidation flow reactors: heterogeneous oxidation, secondary organic aerosol formation and cloud condensation nuclei activity measurements, 
Atmos. Meas. Tech., 4, 445-461, https://doi.org/10.5194/amt-4445-2011, 2011a.

Lambe, A. T., Onasch, T. B., Massoli, P., Croasdale, D. R., Wright, J. P., Ahern, A. T., Williams, L. R., Worsnop, D. R., Brune, W. H., and Davidovits, P.: Laboratory studies of the chemical composition and cloud condensation nuclei $(\mathrm{CCN})$ activity of secondary organic aerosol (SOA) and oxidized primary organic aerosol (OPOA), Atmos. Chem. Phys., 11, 8913-8928, https://doi.org/10.5194/acp-11-8913-2011, 2011 b.

Lambe, A. T., Chhabra, P. S., Onasch, T. B., Brune, W. H., Hunter, J. F., Kroll, J. H., Cummings, M. J., Brogan, J. F., Parmar, Y., Worsnop, D. R., Kolb, C. E., and Davidovits, P.: Effect of oxidant concentration, exposure time, and seed particles on secondary organic aerosol chemical composition and yield, Atmos. Chem. Phys., 15, 3063-3075, https://doi.org/10.5194/acp15-3063-2015, 2015.

Lee, A. K. Y., Hayden, K. L., Herckes, P., Leaitch, W. R., Liggio, J., Macdonald, A. M., and Abbatt, J. P. D.: Characterization of aerosol and cloud water at a mountain site during WACS 2010: secondary organic aerosol formation through oxidative cloud processing, Atmos. Chem. Phys., 12, 7103-7116, https://doi.org/10.5194/acp-12-7103-2012, 2012.

Lee, Y. H. and Adams, P. J.: Evaluation of aerosol distributions in the GISS-TOMAS global aerosol microphysics model with remote sensing observations, Atmos. Chem. Phys., 10, 2129-2144, https://doi.org/10.5194/acp-10-2129-2010, 2010.

Lee, A. K. Y., Herckes, P., Leaitch, W. R., Macdonald, A. M., and Abbatt, J. P. D.: Aqueous $\mathrm{OH}$ oxidation of ambient organic aerosol and cloud water organics: Formation of highly oxidized products, Geophys. Res. Lett., 38, L11805, https://doi.org/10.1029/2011GL047439, 2011.

Liao, H. and Seinfeld, J. H.: Global impacts of gas-phase chemistryaerosol interactions on direct radiative forcing by anthropogenic aerosols and ozone, J. Geophys. Res.-Atmos., 110, D18208, https://doi.org/10.1029/2005JD005907, 2005.

Liggio, J., Li, S.-M., and McLaren, R.: Heterogeneous Reactions of Glyoxal on Particulate Matter:? Identification of Acetals and Sulfate Esters, Environ. Sci. Technol., 39, 1532-1541, https://doi.org/10.1021/es048375y, 2005a.

Liggio, J., Li, S.-M., and McLaren, R.: Reactive uptake of glyoxal by particulate matter, J. Geophys. Res.-Atmos., 110, D10304, https://doi.org/10.1029/2004JD005113, 2005b.

Lim, Y. B., Tan, Y., Perri, M. J., Seitzinger, S. P., and Turpin, B. J.: Aqueous chemistry and its role in secondary organic aerosol (SOA) formation, Atmos. Chem. Phys., 10, 1052110539, https://doi.org/10.5194/acp-10-10521-2010, 2010.

Liu, T., Li, Z., Chan, M., and Chan, C. K.: Formation of secondary organic aerosols from gas-phase emissions of heated cooking oils, Atmos. Chem. Phys., 17, 7333-7344, https://doi.org/10.5194/acp-17-7333-2017, 2017.

Ma, P. K., Zhao, Y., Robinson, A. L., Worton, D. R., Goldstein, A. H., Ortega, A. M., Jimenez, J. L., Zotter, P., Prévôt, A. S. H., Szidat, S., and Hayes, P. L.: Evaluating the impact of new observational constraints on P-S/IVOC emissions, multigeneration oxidation, and chamber wall losses on SOA modeling for Los Angeles, CA, Atmos. Chem. Phys., 17, 9237-9259, https://doi.org/10.5194/acp-17-9237-2017, 2017.

Mahmud, A. and Barsanti, K.: Improving the representation of secondary organic aerosol (SOA) in the MOZART-4 global chemical transport model, Geosci. Model Dev., 6, 961-980, https://doi.org/10.5194/gmd-6-961-2013, 2013.

Mao, J., Ren, X., Brune, W. H., Olson, J. R., Crawford, J. H., Fried, A., Huey, L. G., Cohen, R. C., Heikes, B., Singh, H. B., Blake, D. R., Sachse, G. W., Diskin, G. S., Hall, S. R., and Shetter, R. E.: Airborne measurement of $\mathrm{OH}$ reactivity during INTEX-B, Atmos. Chem. Phys., 9, 163-173, https://doi.org/10.5194/acp-9163-2009, 2009.

Matsunaga, A. and Ziemann, P. J.: Gas-Wall Partitioning of Organic Compounds in a Teflon Film Chamber and Potential Effects on Reaction Product and Aerosol Yield Measurements, Aerosol Sci. Tech., 44, 881-892, https://doi.org/10.1080/02786826.2010.501044, 2010.

Matthew, B. M., Middlebrook, A. M., and Onasch, T. B.: Collection Efficiencies in an Aerodyne Aerosol Mass Spectrometer as a Function of Particle Phase for Laboratory Generated Aerosols, Aerosol Sci. Tech., 42, 884-898, https://doi.org/10.1080/02786820802356797, 2008.

Middlebrook, A. M., Bahreini, R., Jimenez, J. L., and Canagaratna, M. R.: Evaluation of Composition-Dependent Collection Efficiencies for the Aerodyne Aerosol Mass Spectrometer using Field Data, Aerosol Sci. Tech., 46, 258-271, https://doi.org/10.1080/02786826.2011.620041, 2012.

Ng, N. L., Kroll, J. H., Chan, A. W. H., Chhabra, P. S., Flagan, R. C., and Seinfeld, J. H.: Secondary organic aerosol formation from $m$-xylene, toluene, and benzene, Atmos. Chem. Phys., 7, 3909-3922, https://doi.org/10.5194/acp-7-3909-2007, 2007.

Ng, N. L., Canagaratna, M. R., Zhang, Q., Jimenez, J. L., Tian, J., Ulbrich, I. M., Kroll, J. H., Docherty, K. S., Chhabra, P. S., Bahreini, R., Murphy, S. M., Seinfeld, J. H., Hildebrandt, L., Donahue, N. M., DeCarlo, P. F., Lanz, V. A., Prévôt, A. S. H., Dinar, E., Rudich, Y., and Worsnop, D. R.: Organic aerosol components observed in Northern Hemispheric datasets from Aerosol Mass Spectrometry, Atmos. Chem. Phys., 10, 46254641, https://doi.org/10.5194/acp-10-4625-2010, 2010.

Ng, N. L., Canagaratna, M. R., Jimenez, J. L., Chhabra, P. S., Seinfeld, J. H., and Worsnop, D. R.: Changes in organic aerosol composition with aging inferred from aerosol mass spectra, Atmos. Chem. Phys., 11, 6465-6474, https://doi.org/10.5194/acp11-6465-2011, 2011.

Nguyen, T. K. V., Zhang, Q., Jimenez, J. L., Pike, M., and Carlton, A. G.: Liquid Water: Ubiquitous Contributor to Aerosol Mass, Environ. Sci. Tech. Lett., 3, 257-263, https://doi.org/10.1021/acs.estlett.6b00167, 2016.

Ortega, A. M., Hayes, P. L., Peng, Z., Palm, B. B., Hu, W., Day, D. A., Li, R., Cubison, M. J., Brune, W. H., Graus, M., Warneke, C., Gilman, J. B., Kuster, W. C., de Gouw, J., GutiérrezMontes, C., and Jimenez, J. L.: Real-time measurements of secondary organic aerosol formation and aging from ambient air in an oxidation flow reactor in the Los Angeles area, Atmos. Chem. Phys., 16, 7411-7433, https://doi.org/10.5194/acp16-7411-2016, 2016.

Palm, B. B., Campuzano-Jost, P., Ortega, A. M., Day, D. A., Kaser, L., Jud, W., Karl, T., Hansel, A., Hunter, J. F., Cross, E. S., Kroll, J. H., Peng, Z., Brune, W. H., and Jimenez, J. L.: In situ secondary organic aerosol formation from ambient pine forest air using an oxidation flow reactor, Atmos. Chem. Phys., 16, 29432970, https://doi.org/10.5194/acp-16-2943-2016, 2016. 
Peng, Z., Day, D. A., Ortega, A. M., Palm, B. B., Hu, W., Stark, H., Li, R., Tsigaridis, K., Brune, W. H., and Jimenez, J. L.: Non-OH chemistry in oxidation flow reactors for the study of atmospheric chemistry systematically examined by modeling, Atmos. Chem. Phys., 16, 4283-4305, https://doi.org/10.5194/acp16-4283-2016, 2016.

Peng, Z. and Jimenez, J. L.: Modeling of the chemistry in oxidation flow reactors with high initial NO, Atmos. Chem. Phys., 17, 11991-12010, https://doi.org/10.5194/acp-17-11991-2017, 2017.

Romonosky, D. E., Laskin, A., Laskin, J., and Nizkorodov, S. A.: High-Resolution Mass Spectrometry and Molecular Characterization of Aqueous Photochemistry Products of Common Types of Secondary Organic Aerosols, J. Phys. Chem. A, 119, 2594 2606, https://doi.org/10.1021/jp509476r, 2015.

Rudich, Y., Donahue, N. M., and Mentel, T. F.: Aging of organic aerosol: Bridging the gap between laboratory and field studies, Annu. Rev. Phys. Chem., 58, 321-352, https://doi.org/10.1146/annurev.physchem.58.032806.104432, 2007.

Ruehl, C. R., Nah, T., Isaacman, G., Worton, D. R., Chan, A. W. H., Kolesar, K. R., Cappa, C. D., Goldstein, A. H., and Wilson, K. R.: The Influence of Molecular Structure and Aerosol Phase on the Heterogeneous Oxidation of Normal and Branched Alkanes by OH, J. Phys. Chem. A, 117, 3990-4000, https://doi.org/10.1021/jp401888q, 2013.

Sareen, N., Waxman, E. M., Turpin, B. J., Volkamer, R., and Carlton, A. G.: Potential of Aerosol Liquid Water to Facilitate Organic Aerosol Formation: Assessing Knowledge Gaps about Precursors and Partitioning, Environ. Sci. Technol., 51, 3327-3335, https://doi.org/10.1021/acs.est.6b04540, 2017.

Sato, K., Hatakeyama, S., and Imamura, T.: Secondary organic aerosol formation during the photooxidation of toluene: NOx dependence of chemical composition, J. Phys. Chem. A, 111, 9796-9808, https://doi.org/10.1021/jp071419f, 2007.

Seinfeld, J. H. and Pandis, S. N.: Atmospheric Chemistry and Physics: From Air Pollution to Climate Change, 2nd ed., Wiley, Hoboken, NJ, 2006.

Shrivastava, M., Fast, J., Easter, R., Gustafson Jr., W. I., Zaveri, R. A., Jimenez, J. L., Saide, P., and Hodzic, A.: Modeling organic aerosols in a megacity: comparison of simple and complex representations of the volatility basis set approach, Atmos. Chem. Phys., 11, 6639-6662, https://doi.org/10.5194/acp11-6639-2011, 2011.

Smith, M. L., Kuwata, M., and Martin, S. T.: Secondary Organic Material Produced by the Dark Ozonolysis of $\alpha$ Pinene Minimally Affects the Deliquescence and Efflorescence of Ammonium Sulfate, Aerosol Sci. Tech., 45, 244-261, https://doi.org/10.1080/02786826.2010.532178, 2011.

Smith, M. L., Bertram, A. K., and Martin, S. T.: Deliquescence, efflorescence, and phase miscibility of mixed particles of ammonium sulfate and isoprene-derived secondary organic material, Atmos. Chem. Phys., 12, 9613-9628, https://doi.org/10.5194/acp-12-9613-2012, 2012.

Smith, M. L., You, Y., Kuwata, M., Bertram, A. K., and Martin, S. T.: Phase Transitions and Phase Miscibility of Mixed Particles of Ammonium Sulfate, Toluene-Derived Secondary Organic Material, and Water, J. Phys. Chem. A, 117, 8895-8906, https://doi.org/10.1021/jp405095e, 2013.
Song, M., Liu, P. F., Hanna, S. J., Zaveri, R. A., Potter, K., You, Y., Martin, S. T., and Bertram, A. K.: Relative humiditydependent viscosity of secondary organic material from toluene photo-oxidation and possible implications for organic particulate matter over megacities, Atmos. Chem. Phys., 16, 8817-8830, https://doi.org/10.5194/acp-16-8817-2016, 2016.

Takahama, S., Pathak, R. K., and Pandis, S. N.: Efflorescence Transitions of Ammonium Sulfate Particles Coated with Secondary Organic Aerosol, Environ. Sci. Technol., 41, 2289-2295, https://doi.org/10.1021/es0619915, 2007.

Tsigaridis, K., Daskalakis, N., Kanakidou, M., Adams, P. J., Artaxo, P., Bahadur, R., Balkanski, Y., Bauer, S. E., Bellouin, N., Benedetti, A., Bergman, T., Berntsen, T. K., Beukes, J. P., Bian, H., Carslaw, K. S., Chin, M., Curci, G., Diehl, T., Easter, R. C., Ghan, S. J., Gong, S. L., Hodzic, A., Hoyle, C. R., Iversen, T., Jathar, S., Jimenez, J. L., Kaiser, J. W., Kirkevåg, A., Koch, D., Kokkola, H., Lee, Y. H., Lin, G., Liu, X., Luo, G., Ma, X., Mann, G. W., Mihalopoulos, N., Morcrette, J.-J., Müller, J.-F., Myhre, G., Myriokefalitakis, S., Ng, N. L., O'Donnell, D., Penner, J. E., Pozzoli, L., Pringle, K. J., Russell, L. M., Schulz, M., Sciare, J., Seland, Ø., Shindell, D. T., Sillman, S., Skeie, R. B., Spracklen, D., Stavrakou, T., Steenrod, S. D., Takemura, T., Tiitta, P., Tilmes, S., Tost, H., van Noije, T., van Zyl, P. G., von Salzen, K., Yu, F., Wang, Z., Wang, Z., Zaveri, R. A., Zhang, H., Zhang, K., Zhang, Q., and Zhang, X.: The AeroCom evaluation and intercomparison of organic aerosol in global models, Atmos. Chem. Phys., 14, 10845-10895, https://doi.org/10.5194/acp-1410845-2014, 2014.

Volkamer, R., Jimenez, J. L., San Martini, F., Dzepina, K., Zhang, Q., Salcedo, D., Molina, L. T., Worsnop, D. R., and Molina, M. J.: Secondary organic aerosol formation from anthropogenic air pollution: Rapid and higher than expected, Geophys. Res. Lett., 33, L17811, https://doi.org/10.1029/2006g1026899, 2006.

Wong, J. P. S., Lee, A. K. Y., and Abbatt, J. P. D.: Impacts of Sulfate Seed Acidity and Water Content on Isoprene Secondary Organic Aerosol Formation, Environ. Sci. Technol., 49, 13215-13221, https://doi.org/10.1021/acs.est.5b02686, 2015.

Zhang, Q., Worsnop, D. R., Canagaratna, M. R., and Jimenez, J. L.: Hydrocarbon-like and oxygenated organic aerosols in Pittsburgh: insights into sources and processes of organic aerosols, Atmos. Chem. Phys., 5, 3289-3311, https://doi.org/10.5194/acp-5-32892005, 2005.

Zhang, X., Cappa, C. D., Jathar, S. H., McVay, R. C., Ensberg, J. J., Kleeman, M. J., and Seinfeld, J. H.: Influence of vapor wall loss in laboratory chambers on yields of secondary organic aerosol, P. Natl. Acad. Sci. USA, 111, 5802-5807, https://doi.org/10.1073/pnas.1404727111, 2014.

Zhang, X., Schwantes, R. H., McVay, R. C., Lignell, H., Coggon, M. M., Flagan, R. C., and Seinfeld, J. H.: Vapor wall deposition in Teflon chambers, Atmos. Chem. Phys., 15, 4197-4214, https://doi.org/10.5194/acp-15-4197-2015, 2015.

Zhang, Z., Zhang, Y., Wang, X., Lü, S., Huang, Z., Huang, X., Yang, W., Wang, Y., and Zhang, Q.: Spatiotemporal patterns and source implications of aromatic hydrocarbons at six rural sites across China's developed coastal regions, J. Geophys. Res.-Atmos., 121, 2016JD025115, https://doi.org/10.1002/2016JD025115, 2016.

Zhao, Y., Saleh, R., Saliba, G., Presto, A. A., Gordon, T. D., Drozd, G. T., Goldstein, A. H., Donahue, N. M., and Robinson, A. 
L.: Reducing secondary organic aerosol formation from gasoline vehicle exhaust, P. Natl. Acad. Sci. USA, 114, 6984-6989, https://doi.org/10.1073/pnas.1620911114, 2017. 